\title{
Historical foundation of diversity courses in teacher education programs and challenges of pedagogic application
}

\author{
Michael Takafor Ndemanu
}

\begin{abstract}
This article examines the historical underpinnings of multicultural education with respect to its origin, goals, and struggles for implementation in public schools prior to the 1970s. It also discusses the impeding factors that have up to now hampered an effective multicultural education preparation for preservice teachers, who are expected to acquire instructional strategies grounded in the core values of multicultural education in order to be effective teachers of diverse student populations. The setbacks, otherwise known as areas of concerns in multicultural teacher education courses, are explored in this article and classified as unpreparedness of middle-class white preservice teachers, scope of the curriculum and pedagogy, preservice teachers' deficit beliefs, preservice teachers' resistance to diversity and equity courses, racial identities of the instructors of diversity courses, and direct experiences. The examination of the setbacks are meant to raise awareness of the intricacies of teaching diversity and equity courses for teacher educators, and not to discount the contribution of such courses in inculcating cross-cultural awareness and praxis in prospective teachers.
\end{abstract}

\section{Introduction}

The purpose of diversity and equity courses is predicated on the premise that even though the US student population is becoming increasingly diverse, the teaching force remains predominantly monolingual, white, female, and middle-class (Milner, 2005). Thus, diversity and equity courses in teacher education programs were designed in the 1970s, in order to raise the preservice teachers' (PSTs) awareness of and sensitivity to the ever-growing diversity of student populations in US classrooms following the Brown vs. Board of Education landmark case. This culminated in a court ruling for racial integration of public schools in 1954 (Rountree, 2004). These courses were also designed to counteract PST beliefs that are antithetical to social justice, by infusing diversity and equity issues into the course and inculcating critical consciousness into the PSTs' thought processes so as to facilitate the unlearning of racialized (Cochran-Smith, 2000), homophobic, and genderbiased curricula (Banks \& Banks, 1993). In order to understand the rationale of introducing multicultural education courses into teacher education, we must first look at the current US demographic with respect to education. According to the US Census Bureau (2000), culturally, linguistically and economically different (CLED) students will represent about half of the US school-aged population by 2020. In addition, the US remains the most religiously diverse country in the world (Eck, 2001). While the CLED student population is 
increasing, the population of CLED teachers is dwindling (Nieto, 2000). An average eighth grader of color tends to compete only with an average white fourth grader (National Center for Educational Statistics, 2003). It is due to such a cultural and statistical disequilibrium between CLED students and the middle-class, white, female teachers that diversity and equity (DE) courses were introduced in many teacher education programs in the mid1970 s in order to raise the cultural competency and sensitivity of the latter for the rapidly growing CLED school-aged population in urban areas. Understanding the historical context that led to the creation of DE courses so as to equip the PSTs with the necessary crosscultural pedagogic tools in order to function effectively in diverse classrooms is vital in gauging the effectiveness of such courses. In the subsequent sections, the historical background of the creation of DE courses in teacher education, as well as areas of concern in multicultural teacher education, will be examined.

\section{Government Legislation and the History of Multicultural Education}

Multicultural education had existed in many forms for decades before the passage of the Civil Rights Act of 1964, which led to the legitimization of the field. Although several attempts to institute multiculturalism in public schools had occurred before this passage, its implementation was only made possible when the federal government began enacting policies that validated multicultural education's core principles. These include the Civil Rights Act and the passage of Title IX of the Elementary and Secondary Education Act of 1965 (ESEA) from which the Ethnic Heritage Studies Program Act of 1972 emerged (Baker, 1979). The latter contributed to the creation of ethnic studies programs in many universities, which led to the development and expansion of scholarship on different ethnic groups and their cultures. The Bilingual Education Act of 1968, which was enacted in order to address language barrier issues, also fertilized the ground for broad multiculturalism, which could no longer be limited to only ethnic studies. These acts not only prohibited discrimination on the basis of race, ethnicity, language, physical and mental ability, and gender, but also allocated funding for their respective implementations. For example, the Bilingual Education Act funded bilingual educational programs.

The passage of the Equal Educational Opportunity Act of 1974, which sought to overcome barriers to equal educational opportunities, ended the perennial problem of the segregation of public schools on the basis of race across the country, while unintentionally creating another problem: that of the cultural incongruity between white teachers and students of color. The emergence of problems associated with cultural mismatch and achievement gaps, which have preoccupied educational researchers for the past four decades, will continue as long as residential segregation persists.

In 1975, the US Congress passed the Education for All Handicapped Children Act, which required any public schools receiving federal funds to provide equal access to education for all children with disabilities. The passage of this legislation led to the inclusion of disabilities as a theme in multicultural education. The enactment of the foregoing legislations at different times explains the minimally integrated nature of the content of multicultural teacher education curriculum since its inception. Although a number of founding scholars of multicultural education (see Sleeter \& Grant, 2003; Banks \& Banks, 1999; Nieto, 1998; Gollnick \& Chinn, 1998; Gay, 1975) thought of it in terms of 
interlocking systems of oppressions that should incorporate complete multiple perspectives from different groups rather than fragmented concepts, the reality was something else, given their diverse individual scholarly strengths in ethnic studies, gender studies, special education, and race and ethnicity.

However, a great deal of credit for the success of multicultural education and multicultural teacher education should go to the states and their boards of education, which took further measures to translate into reality the federal legislation geared toward leveling the playing field for all children. A case in point is the Ann Arbor (Michigan) Public School System, which, in conjunction with the Ann Arbor Education Association, designed a new teacher certification policy that stated:

Beginning in the 1972-1973 school year, no student teacher shall be accepted by the Ann Arbor Schools unless he can demonstrate attitudes necessary to support and create the multiethnic curriculum. Each such student teacher must provide a document or transcript which reflects training in or evidence of substantive understanding of the multiethnic or minority experience. (Baker, 1977, p. 164)

It was in response to similar policies around the country that many teacher education programs began hiring social justice teacher educators to design and teach mandatory multicultural education courses.

The National Council for the Accreditation of Teacher Education (NCATE) played a less significant role in the multiculturalization of teacher education programs, in spite of the influential position it has occupied in the realm of teacher education for decades. However, its contribution cannot be completely dismissed because, prior to January 1, 1979 , adherence to the pedagogic principles of multicultural education was not part of NCATE's general standards. After this date, these standards were revised and expanded to include such requirements (Baker, 1979). These NCATE standards, in general, have contributed tremendously to the professionalization of teaching, and have translated into more accountability in terms of teacher quality (Murrell, 2001). Some of the key elements of the NCATE standards, which student teachers are required to fulfill in order to teach in the US, include a commitment to "apply effective methods of teaching students who are at different developmental stages, have different learning styles, and come from diverse backgrounds," and the ability to "understand the impact of discrimination based on race, class, gender, disability/exceptionality, sexual orientation, and language on students and their learning" (NCATE, 2008, p. 7). Teacher education programs seeking NCATE accreditation for the first time and those that wish to remain accredited strive to meet all of NCATE's standards, thereby paving the way for the continuous existence of multicultural teacher education. Even though it would be unfair to give NCATE an outstanding grade when teachers who have graduated from some of its accredited schools are still illprepared to teach in ethnically and linguistically diverse urban schools (Murrell, 2001), rejecting the professionalization of teachers and discrediting the work of NCATE and teacher colleges in some states undermines the great strides attained so far in teacher education reforms (Cochran-Smith, 2003). 
In order to fully understand the meaning of multicultural education, we need to start by defining the term culture as understood by multicultural education scholars when applied to an educational setting. Culture in multicultural education is defined as "a social group's design for surviving in and adapting to its environment" (Banks \& Banks, 1999, p. 29). This definition does not limit itself to the heritage and traditions of a social group and can include sexism, sexual orientation, ageism and whatever factors a social group deems worthy of consideration. Banks (1993) defined multicultural education as "a reform movement that is trying to change the schools and other educational institutions so that students from all social-classes, genders, and racial and cultural groups, including all children with disabilities, will have an equal opportunity to learn" (p. 4). It is worth noting that the main goal of multicultural education was initially focused on fighting specifically for equality of educational opportunities for African-American children. As stated earlier, multicultural education broadened in the mid-1970s to include other minority ethnic groups, classes, genders, sexual orientations, and disabilities. This history is indicative of trends and issues rather than an exhaustive account, given the broad nature of the field and the large number of scholars theorizing about different ethnic and social groups.

\section{Origin and Original Goals of Multicultural Education}

In order to have a better understanding of the history of multicultural education in teacher education, it is important to trace the origins and original goals of the reform movement. According to Banks (1993) and Boyle-Baise (1999), multicultural education originated during the Civil Rights Movement of the 1960s, which had its roots in early black historians, such as Carter G. Woodson and W. E. B. DuBois. This was the period in which African-Americans' struggle against inequities in social services culminated in the passage of a law that guaranteed them the right to vote, concomitant to the birth of multicultural education. Banks's delineation of the origin of multicultural education focuses predominantly on African-Americans. Other social, gender and ethnic groups joined the movement at a later stage.

Payne and Welsh (2000) posit that the origin of multicultural education can be traced as far back as the 1840s when Catholics and German-Americans requested a more inclusive education (see also Glazer, 1995). These authors identified, for example, a struggle in the 1880s for the rights of the children of German immigrants to receive instruction in German. This effort culminated in the adoption of a German language option in several cities across the US, including St. Louis, Cincinnati, and Indianapolis, contrary to the wishes of assimilationists, who thought that immigrants should learn the English language and American culture instead of advocating their own. By the mid-1880s, there were about 300 German-English schools, mostly located in the rural Midwestern part of the US (Ramsey, 2010).

According to Montalto (1982), Rachel Davis DuBois, who was the first executive of the Service Bureau for Intercultural Education in the US, was the initiator of multicultural education. At that time, it was called intercultural education and focused more on equity, peace and racial tolerance, and less on ethnic studies. Her struggle for equal education for both African-Americans and whites in the 1920s and 1930s attracted considerable criticism. Her mission was to help people see their shared humanity and understand the 
contributions of all cultural groups with regard to harmony and world peace (Montalto, 1982). Although DuBois played an influential role in the struggle for educational equality in the 1920s and 1930s, her foundational contributions in multicultural education research have remained largely unrecognized.

The indisputable precursor to a more popular version of multicultural education was the social action led by African-Americans and followed by white liberals and other people of color who marched during the Civil Rights Movement against 1960s racial segregation in the US (Banks \& Banks, 1999; Davidman \& Davidman, 1997). These individuals called for equal educational opportunities, curricular adjustments and hiring practices that encouraged diversity in the teaching force. As Ladson-Billings (1995) posited, a predominantly African-American school with a predominantly white academic staff and a predominantly African-American janitorial staff did not inspire the AfricanAmerican students to be ambitious in school and, as a result, their grades suffered. This underrepresentation of ethnic minorities in white collar jobs explains why multiculturalists advocated diversity in school hiring practices. Note that in the early 1970s, the field was known as multiethnic education. It was thanks to the federal government's legislation of the 1970s that other groups (the handicapped, women, language minorities) who were affected by these laws began advocating for the inclusion of their respective group memberships. This, in turn, led scholars of the field to switch to the current nomenclature, multicultural education, in a bid to be more ecumenical.

In the 1970s, women's rights activists joined the struggle for educational, employment, and income equity. They insisted on school curricula that integrated women's history and experiences, and demanded an end to discriminatory hiring practices that limited women's opportunities to administrative posts. By the mid-1970s, other oppressed groups, such as gays, lesbians, the elderly, and people with disabilities, began insisting on equal civil and human rights (Banks \& Banks, 1999).

\section{Implementation of Multicultural Education}

Beginning in the 1960s, a metaphorical shift emerged in regard to immigrants' acculturation processes. The US was no longer known as a "melting pot," but was, instead, known as a "salad bowl," a change freeing all groups to assert their rights to maintain their cultural identities and demand their own share of equal educational opportunities (Gezi, 1981). This change caused more multicultural programs to be created and various states to enact legislations to guide the implementation of multicultural education in both teacher education programs and K-12 schools (Giles, 1978). In the mid-1970s, a survey of 395 teacher education establishments showed that most were operating multicultural-related programs (Gollnick, 1980). However, a misunderstanding still existed among educators as to how to proceed with the implementation of a multicultural curriculum. Should children with minority backgrounds be offered remedial education in order to improve their achievement levels to those of mainstream students (Gezi et al., 1981)? Other researchers like Ramirez \& Castaneda (1974) had previously considered the question to be inappropriate, as it meant accepting that minority cultures were not only different, but also deficient. They proposed a school situation in which every group maintained its cultural identity, but contributed to the rich diversity of American society. The underpinnings of 
this debate shaped the conceptualization of instruction in multicultural teacher education. This paradigm navigation between the "salad bowl" and "melting pot" metaphors still has a tremendous pedagogic influence on instructors of multicultural education courses today in regard to how they teach courses.

According to McLaren (1994), Jenks et al. (2001), and Gorski (2009), the framework for multicultural teacher pedagogy falls under the following categories: conservative multiculturalism, liberal multiculturalism, and critical multiculturalism. Conservative multicultural instructors tend to design their instruction with the goal of achieving cultural homogeneity at the expense of cultural heterogeneity within a macroculture (Jenks et al., 2001). Liberal multiculturalism, the most popular pedagogic method in multicultural teacher education, is predicated on the values of human diversity and the need for sensitivity on the part of the prospective teachers with regard to a variety of issues pertaining to human diversity when dealing with CLED students. However, it fails to instill the critical postmodernist epistemology necessary for the PSTs to challenge the power relations and injustices within society. It is at this stage that critical multiculturalism is considered indispensable, because it imparts critical consciousness to the PSTs so that they can learn to detect injustices as well as work for social justice in a proactive manner.

\section{The Struggles of Multicultural Teacher Education}

For over four decades, DE courses have gained ground nationally in teacher education programs. The issues that some researchers have identified as impediments to multicultural education goals in teacher education programs are classified as follows in terms of areas of concerns: unpreparedness of middle-class, white PSTs; scope of the curriculum and pedagogy; PSTs' deficit beliefs; PSTs' resistance to DE courses; racial identities of the instructors of diversity courses; and direct experiences.

\section{Unpreparedness of Middle-Class, White, Female PSTs to Teach CLED Students}

In 1969, a task force report from the National Institute for Advanced Study in Teaching Disadvantaged Youth, Teachers for the Real World, stated that a failure exists in regard to teacher education programs successfully educating PSTs to become multiculturally competent. In this report, cited by Zeichner (1996), three problems that affect teachers' abilities to teach CLED students were raised:

Teachers were unfamiliar with the backgrounds of poor students and the communities where they live, teacher education programs have ordinarily done little to sensitize teachers about their own prejudices and values, and teachers lack preparation in the skills needed to perform effectively in the classroom. (p. 526)

This 1969 report further suggested that PSTs were prepared to teach suburban, middleclass students, but not CLED students. In calling for a total overhaul of teacher education programs to reflect the changing demographic in the public school population, Smith (1969) stated:

Racial, class and ethnic bias can be found in every aspect of current teacher education programs. The selection process militates against the poor and minorities. 
The program content reflects current prejudices; the methods of instruction coincide with the learning styles of the dominant group. Subtle inequalities are reinforced in the institutions of higher learning. Unless there is scrupulous selfappraisal, unless every aspect of teacher training is carefully reviewed, the changes initiated in teacher preparation as a result of the current crisis will be, like so many changes which have gone before, merely differences which make no difference (pp. 2-3).

Surprisingly, four decades after the publication of the above report, the same complaints about teacher education remain commonplace. In 1987, NCATE found that out of the 59 teacher education schools that requested accreditation, only eight met the minimum requirements for multicultural education standards (Zeichner, 1996). A few years later, Ladson-Billings (1990) reported that many teachers graduating from teacher education programs were refusing to teach in urban settings where culturally and linguistically different students abounded, due to their ill-preparedness and unwavering stereotypical beliefs:

Schools and colleges of teacher education are turning out class after class of young, white female teachers who would rather work in white, middle-class suburbs. Unfortunately, their services are most needed in low-income schools, whose students come from races, cultures and language groups for whom these new teachers feel unprepared. (p. 25)

The unwillingness of PSTs to teach in urban schools even after taking a multicultural education course, like DE, is a huge concern for teacher educators in general and multicultural teacher educators in particular.

\section{Preservice Teachers' Beliefs and Predispositions}

Richardson (1996) postulated that beliefs correlate with constructivist theories, and stated that PSTs start education programs with beliefs that strongly influence their perception of multicultural education course content. Their educational backgrounds and sociocultural experiences have a huge impact on their beliefs; therefore, it is critical to understand that beliefs should not be viewed only as something inappropriate, as there are as many positive beliefs as there are negative ones, depending on one's social location and cultural values. Hence, what might be considered a negative belief by one could be a positive belief for another. One of the goals of a multicultural education course is to influence beliefs and attitudes vis-à-vis minority students with respect to their learning abilities. As Green (1971) stated, teaching has to do, in part at least, with the formation of beliefs, and that means that it has to do not simply with what we shall believe, but with how we shall believe. Teaching is an activity that has to do, among other things, with the modification and formation of belief systems (p. 48).

One might wonder to what extent these beliefs are being modified and/or formed in DE courses. If any positive beliefs are being formed, there is still no general consensus as to whether the shift is thanks to DE courses or college courses as a whole. 
Personal school experiences influence PSTs' beliefs and attitudes about cultural inclusiveness. They do not come into the program tabulae rasae, but instead, come in with their own stereotypes about other people's children (Delpit, 2006) that emanate from their early socialization. Worthy of note is the fact that some PSTs have had more "real-life experiences with cultural diversity than others" (Boyle-Baise, 1996, p. 14). There is no gainsaying that PSTs' past experiences in grade school impact the way in which they perceive teaching in general:

Personal experience includes aspects of life that go into the formation of world view; intellectual and virtuous dispositions; beliefs about self in relation to others; understanding of the relationship of schooling to society; and other forms of personal, familial, and cultural understanding. Ethnic and socioeconomic background, gender, geographic location, religious upbringing, and life decisions may all affect an individual's belief that, in turn, affect learning to teach and teaching. (Richardson, 1996, p. 105)

What is factual about Richardson's analysis is that our socialization plays a huge role in forming and reforming our beliefs. Some of the beliefs that prospective teachers bring into the teacher education programs are perennial. Modifying them requires a robust multicultural curriculum that takes into consideration the sources of their information and knowledge construction concurrently with the cultural differences that exist between them and their potential CLED students. Teaching strategies that involve reawakening the prospective teachers' critical consciousness are necessary so that they can challenge some of their beliefs about diverse student populations. The PSTs' beliefs about instruction as well as their experiences as students also impact the way in which they learn and teach. This attitude is similar to the adage that teachers tend to teach the way they were taught instead of the way they were trained to teach. In addition, many PSTs whose role models are their former teachers tend to embrace the teaching philosophies of the latter (Crow, 1988). On studying beliefs held by PSTs on special education, Brantlinger (1996) concluded:

These university students had images and ideas of how to teach, what school is for, good and bad parents, and the characteristics of individuals from their own and other social classes. They had personal theories about how people learn and the purpose of education. They readily applied these common sense notions to their experiences in the teacher preparation program. (p. 29)

The personal theories that PSTs hold about education and "other people" ultimately affect the way that they experience the content of multicultural education courses.

\section{PSTs' Resistance to Multicultural Education Courses}

Many PSTs believe that not every student can learn (Guerra \& Nelson, 2009). This deficit thinking about CLED students, in turn, influences how PSTs teach CLED students when they become teachers (Zeichner \& Hoeft, 1996). Conversely, high expectations for CLED students breed higher academic achievement. Hilliard (1974) argued that the poor academic achievements of CLED students are a result of teachers' low expectations for their 
students. The major source of these low expectations is the teachers' negative beliefs about what CLED students can and cannot do. In order to alter this deficit thinking, teacher educators should refocus the attention of PSTs towards articles and/or readings that carry cases of success in teaching CLED students (Zeichner \& Hoeft, 1996). Most people who stigmatize others do so as a result of ignorance. Many PSTs do not know the history of CLED students and this absence of historical knowledge leads to unreflective assumptions and negative stereotypes of the latter's academic abilities. Ellwood (1990) argued for the inclusion of ethnic studies in teacher preparatory programs so that prospective teachers would have more time to learn about the history of disadvantaged ethnic groups. However, he failed to include other minorities, such as the disabled, women, and students from low socioeconomic backgrounds. PSTs may never be fully prepared to teach CLED students if ethnic studies are not a part of the curriculum in teacher education programs.

Talking about the impact of African-American history in the US, Malcolm X stated:

If we don't go into the past and find out how we got this way, we will think that we were always this way. And if you think that you were in the condition that you're in right now, it's impossible for you to have too much confidence in yourself, you become worthless, almost nothing. (Tosh \& Lang, 2006, p. 5)

While it is important to learn about the history of CLED students in order to have a better understanding of who they are, a danger exists in such knowledge causing accusations and counteraccusations on the part of the PSTs. It is very common to hear white PSTs say, "My great-grandparents never owned slaves." This defensive mechanism is often used when structural inequalities in society are being examined.

According to Finney and Orr (1995), while PSTs learn about cultural inclusion in their multicultural education courses, the courses often fail to negate the PSTs' beliefs about privileges that only some ethnic groups enjoy. Weisman and Garza (2002) conducted an evaluation of PSTs' beliefs about diversity at a university in California and arrived at the following conclusion:

Although by the end of the multicultural course there was an overall positive orientation to diversity, the low levels of agreement for certain key items on both the pre- and post-surveys are cause for concern. The majority of these preservice teachers began the semester with a perspective that was oriented toward blaming minority students and their families for a lack of educational success rather than looking at factors within the structure of schooling or society as possible sources of educational difficulties. (p. 32)

In the same vein, Haberman \& Post (1992) postulated that if any positive changes have occurred in the PSTs' beliefs, they have been marginal; while Kagan (1992) stated that "candidates tend to use the information provided in the coursework to confirm rather than to confront and correct their preexisting beliefs" (p. 154). This debate leads to the issue of predispositional factors that some researchers have documented as contributing to changing perceptions. Smith, Moallem and Sherrill (1997) found that four factors (education, travel, experience with discrimination, and exposure to different cultures) 
contributed to a positive change in prospective teachers' beliefs about teaching CLED students.

The above arguments bring us to the following question: Are PSTs from diverse campuses more predisposed to embrace diversity in all its forms than those from homogenous campuses? In attempting a response to this question, Garmon (2004) carried out a case study on a prospective teacher who had taken his course on multicultural education. He summed the results of his findings into six major factors that influenced his student's change of attitude. The six factors were categorized as followed: openness, selfawareness, commitment to social justice, intercultural experiences, support group experiences, and educational experiences. In addition, he called for intercultural experiences as a prerequisite for admission into the teacher education program, since these experiences are instrumental in opening people's minds to multicultural education literature.

Although Leslie [Garmon's student] began her teacher education program with favorable dispositions for learning about diversity, it was her intercultural experiences that actually stimulated her multicultural growth by pushing her out of her comfort zone and challenging her to re-examine her racial attitudes and beliefs. (p. 212)

The results of this study throw additional light on the PSTs' resistance to human diversity issues and how this resistance could be limited or deterred in teacher education programs.

Ross and Smith (1992) noticed incremental gains in students' knowledge and attitudes with respect to the socioeconomic and political factors that contributed to the academic underachievement of nontraditional students when the PSTs in the study took a semester-long multicultural education course. Despite this, Pohan (1996) posited that preservice teachers who come into teacher education programs with higher levels of entrenched biases about diversity were less likely to internalize any instructional content that might influence their beliefs and attitudes. According to Brown (2004), this resistance is manifested in the following ways: unwillingness to participate in class discussions, lack of passionate engagement in post-reading discussions, and low rating of the courses and instructors.

As Taylor and Sobel (2001) suggested, the solution to training PSTs how to teach CLED students should not be limited to methodologies and approaches, "but rather in understanding how teachers' beliefs, attitudes and dispositions are interwoven with their knowledge, skills and behaviors of classroom teaching" (p. 489). It is therefore critical for teacher educators to take into consideration the results of the different research findings so far obtained on PSTs' beliefs and attitudes toward diversity as they design their syllabi and plan instructions. Given that "we are what we know. We are, however, also what we do not know" (Cochran-Smith, 2000, p. 169), it is of paramount importance for multicultural education courses to be oriented toward elevating the PSTs' critical consciousness about individual beliefs vis-à-vis CLED students, for it is only when a problem is identified that a solution can be sought. 


\section{A Teacher Educator's Race and Ethnicity}

Another concern of paramount importance in multicultural teacher education is the symmetric demographics of the PSTs and their instructors (Gay, 1997; Lowenstein, 2009). Eighty percent of education faculty members are white and $63 \%$ have grown up in suburbia, which is "segregated" from people of color. Less than $1 / 3$ has travelled outside of the US (MacDonald, Colville-Hall, \& Smolen, 2003). This limited exposure to people of color affects the way that PSTs view racially different faculty members as their instructors, especially in terms of whether the instructor can relate to their experiences. This limited exposure also explains why white PSTs taking DE courses tend to lump the "message" (the course content) and the "messenger" (the instructor) together, especially when the concept of racial discrimination is being taught by an instructor who is a member of a historically oppressed racial or ethnic group (Dixson \& Dingus, 2007).

Many studies have shown that a number of white PSTs are prejudiced toward CLED students and tend to have low academic expectations for them (Irvine, 1991; Delpit, 1995; Darling-Hammond et al., 2005; Guerra \& Nelson, 2009). In order to counter this deficit thinking, Justiz and Kameen (1988) and Haberman (1989) called for the recruitment of qualified PSTs of color, given that they tend to harbor predispositional factors which contradict CLED students' negative expectations of their white teachers.

While some multicultural education researchers believe that the best teachers of CLED students are teachers of color, since they can easily relate to the students' experiences (Haberman, 1991), white PSTs also believe that American-born people of color, especially African-Americans, should not be instructors of multicultural education courses because they have an undisclosed agenda resulting from the country's history of slavery and racial discrimination:

My group talked about our concern with having an ethnic professor teach a course on equity and diversity. We are concerned that they will have an agenda. It might be better to have another professor teach the course so that students get a broader perspective. (Dixson \& Dingus, 2007, p. 639)

As stated earlier, white PSTs seem not to be only resistant to the "message," but also the "messenger," depending on the latter's racial and ethnic background. Talking about the incongruity of PSTs' perspectives and experiences with those of their instructors of another race, one PST in Cochran-Smith's (2000) study said, “Marilyn, I think that you are very brave and genuine to ask the tough questions that you ask your white students. But the truth is, your perspective, your reality, does not necessarily reflect ours" (p. 173). This criticism and a host of others from PSTs of color gave her the opportunity to approach the multicultural course from a more critical angle in order to "unlearn" racism as a text embedded in teacher education.

According to Housee (2008), the lecturer's racialized identity is a huge factor for PSTs in determining the receivability of the course content. While African-American instructors may be prejudged by white PSTs for their "loyalties and sensibilities" to African-Americans, doubts are cast by African-American PSTs on white lecturers' abilities to empathize with victims of racism and understand racial issues. In Dixson and Dingus's 
(2007) study, white PSTs treated one African-American author with suspicion, just as some African-American students viewed their white instructors as being insensitive to and insensible with regards to teaching race-related courses (Housee, 2008):

Some [black] students felt that the white lecturers were their enemies. My presence tremendously challenged them. I would enter the classroom for a battle and often won. Sometimes black students don't like the idea of a white lecturer teaching about "race" and racism. It was challenging. I have to draw from my own background-an anti-Semitic experience-to legitimize my teaching. (p. 424)

In the foregoing quote, the instructor has to identify an element of historical oppression from his own background in order for his students to relate to him. In a similar vein, female instructors often have to draw on the history of oppression of women to boost their credentials to handle any course that covers racism and other "isms."

Similar criticisms have been made by seasoned multicultural education experts about white instructors with limited cross-cultural experiences teaching diversity and equity issues to white PSTs (Gay, 1997; Ladson-Billing, 1995). Zeichner (1996) posited that "most of the education faculty who must be counted on to improve the preparation of teachers for diversity are as lacking in interracial and intercultural experiences as their students" (p. 138). Howard (2006) asked, "Can they teach what they do not know? What is it that they have to know in order to comfortably teach CLED students or be accepted by the latter to teach them?" There seems to be an absence of that community teacher "who possesses contextualized knowledge of the culture, community and identity of the children and families he/she serves and draws on this knowledge to create the core teaching practices necessary for effectiveness in diverse setting" (Murrell, 2001, p. 52). In response to Murrell's call for community teachers, Boyle-Baise (2005) advocated multicultural service learning for PSTs with the goal of affirming diversity, critiquing inequality and building inclusive community with low SES and people of color, while paying special attention to their local needs and knowledge base. The absence of this cultural repertoire and community knowledge of teacher educators diminishes their abilities to make clear-cut connections between concepts and real-life situations. The absence of an educator's community knowledge has an adverse impact on PSTs just as the absence of the community knowledge of the latter diminishes their teaching output in predominantly CLED classrooms.

\section{Conclusion}

DE courses in teacher education programs are fraught with sensitive issues about human diversity. The issues covered in DE courses are considered sensitive in nature to many PSTs because their beliefs and ideologies about race, poverty, religion, Standard English, LGBT (Lesbian, Gay, Bisexual, and Transgendered), gender, and tracking are formally challenged by the readings and instructors of the course. Understanding the goals and history of multicultural education is just as important as understanding the inherent problems that plague the field, as elaborated in the section on the struggles of multicultural education. 
Resistant theorists in the field of education have generally focused on CLED students who resist the formal education taught from the perspective of Anglo-American educators, and neglected the resistance manifested by white PSTs in courses that focus on social justice for the oppressed groups. Although some educational researchers have written about white PSTs' resistance to the main tenets of multiculturalism (Brown, 2004; Finney \& Orr, 1995; Weisman \& Garza, 2002; Haberman \& Post, 1992; Kagan, 1992; Smith, Moallem, \& Sherrill, 1997; Garmon, 2004; Zeichner \& Hoeft, 1996), many have overlooked the transactional pedagogic dimension as propounded by Knight-Abowitz (2000) in which resistance becomes a teachable moment for PSTs to have a profound reflection on their deep-rooted assumptions about diversity. According to Knight-Abowitz, instructors should interpret resistance as a communicative style emanating from social and political standpoints from which a new level of inquiry could be elicited from the students. Thus, using transactional inquiry methodology to comprehend and respond to the PSTs' resistance on diversity-related issues is grounded on the premise that, "communication is the making of something in common in which two or more humans modify their individual experiences through joint activity" (p. 883).

However, white PSTs' resistances to some of the tenets of multicultural education associated with race and socioeconomic status should be expected. It should not be ipso facto construed as being racist because many of the class readings are stereotypical of Anglo-Americans. PSTs could be challenged to critically reflect on their assumptions about people of color without necessarily stereotyping and/or vilifying Anglo-Americans.

\section{References}

Baker, C. G. (1977). Development of the multicultural program: School of Education, University of Michigan. In F. Klassen \& D. Gollnick (Eds.), Pluralism and the American teacher: Issues and case studies (pp. 163-169). Washington, DC: American Association for Colleges of Teacher Education.

Baker, C. G. (1979). Policy issues in multicultural education in the United States. The Journal of Negro Education, 48(3), 253-266.

Banks, J. A. (1993). Multicultural education: Historical development, dimensions, and practice. Review of Research in Education, 19, 3-49.

Banks, J. A. \& Banks, C. A. (1999). Multicultural education: Issues and perspectives. Boston: Allyn \& Bacon.

Boyle-Baise, M. (1996). Multicultural social studies: ideology and practice. Social Studies, 87(2), 81-88.

Boyle-Baise, M. (2005). Preparing community-oriented teachers: Reflections from a multicultural service-learning project. Journal of Teacher Education, 56(5), 446-458.

Boyle-Baise, M. (1999). Bleeding boundaries or uncertain center? A historical exploration of multicultural education. Journal of Curriculum and Supervision, 14(3), 191-215.

Brantlinger, E. (1996). Influence of preservice teachers' beliefs about pupil achievement on attitudes toward inclusion. Teacher Education and Special Education, 19(1), 17-33. 
Brown, L. E. (2004). What precipitates change in cultural diversity awareness during a multicultural course: The message or the method? Journal of Teacher Education, 55(4), 325.

Cochran-Smith, M. (2000). Blind vision: Unlearning racism in teacher education. Harvard Educational Review, 70(2), 157-190.

Cochran-Smith, M. (2003). Standing at the crossroads: Multicultural teacher education at the beginning of the 21st century. Multicultural Perspectives, 5(3), 3-11.

Crow, N. (1988). A longitudinal study of teacher socialization: A case study. Paper presented at the annual meeting of the American Educational Research Association.

Darling-Hammond, L., Hammerness, K., Grossman, P., Rust, F., \& Shulman, L. (2005). The design of teacher education programs. In L. Darling-Hammond \& J. Bransford (Eds.), Preparing teachers for a changing world: What teachers should learn and be able to do (pp. 390-441). San Francisco, CA: Jossey-Bass.

Davidman, L., \& Davidman, P.T. (1997). Teaching with a multicultural perspective: $A$ practical guide. New York: Longman.

Delpit, L. D. (1988). The silenced dialogue: Power and pedagogy in educating other people's children. Harvard Educational Review, 58(3), 280-298.

Delpit, L. (2006). Other people's children: Cultural conflict in the classroom. New York: The New Press.

Dixson, A.D., \& Dingus, J. E. (2007). Tyranny of the majority: Re-enfranchisment of AfricanAmerican teacher educators teaching for democracy. International Journal of Qualitative Studies in Education, 20(6), 639-654.

Eck, D. L. (2001). A new religious America: How a "Christian country" has become the world's most religiously diverse nation. New York: Harper.

Ellwood, C. (1990). The moral imperative of ethnic studies in urban teacher education programs. In M. Diez (Ed.), Proceeding of the fourth national forum of the Association of Independent Liberal Arts Colleges for Teacher Education (pp. 1-6). Milwaukee: Alverno College.

Finney, S., \& Orr, J. (1995). "I have really learned a lot, but ...": Crosscultural understanding and teacher education in a racist society. Journal of Teacher Education, 46(5), 327333.

Garmon, S. A. (2004). Changing preservice teachers' attitudes/beliefs about diversity: What are the critical factors? Journal of Teacher Education, 55(3), 201-212.

Gay, G. (1975). Organizing and designing culturally pluralistic curriculum. Educational Leadership, 33(3), 176-183.

Gay, G. (1997). Multicultural infusion in teacher education: Foundations and applications. Peabody Journal of Education, 72(1), 150-177.

Gezi, K. I., Bradford, A., \& McLean, G. M. (1980). The mystery of the blind writer. Chicago: Children's Press. 
Gezi, K (1981). Issues in Multicultural Education. Educational Research Quarterly, 6(3), 514.

Giles, R. (1978). State legislation, provisions and practices related to multicultural education. Washington, DC: Mimeo.

Glazer, N. (1995). A new word for an old problem: Multicultural "school wars" date to the 1840s. Annual Editions: Multicultural Education, (summer), 74-77.

Gollnick, M. D. (1980). Multicultural education. In A. C. Grant \& K. T. Chapman (Eds.), History of Multicultural Education, Vol. 1 (pp. 35-48). New York: Routledge.

Gollnick, M. D., \& Chinn, P. C. (1998). Multicultural education in a pluralistic society. Columbus, OH: Pearson Merrill Prentice House.

Gorski, P. (2009). Intercultural education as social justice. Intercultural Education, 20(2), 87-90.

Green, T. (1971). The activities of teaching. New York: McGraw-Hill.

Guerra, L. P., \& Nelson, W. S. (2009). Changing professional practice requires changing beliefs. Phi Delta Kappan, 90(5), 354-359

Haberman, M. (1989). More minority teachers. Phi Delta Kappan, 70(10), 771-776.

Haberman (1991). Can Cultural Awareness Be Taught in Teacher Education Programs? Teaching Education, 4(1), 25-32.

Haberman, M., \& Post, L. (1992). Does direct experience change education students' perception of low-income minority children? Mid-Western Educational Researcher, 5(2), 29-32.

Hilliard, A. (1974). Restructuring teacher education for multicultural imperatives. In W. A. Hunter (Ed.), Multicultural education through competency-based teacher education (pp. 40-55). Washington, DC: AACTE.

Housee S. (2008). Should identity matter when teaching about "race" and racism in the classroom? Race Ethnicity and Education, 4, 415-428.

Howard, G. R. (2006). We can't teach what we don't know: White teachers, multiracial schools. New York: Teachers College Press.

Irvine, J. J. (1991). Black students and school failure. New York: Praeger.

Jenks, C., Lee, J. O., \& Kanpol, B. (2001). Approaches to multicultural education in preservice teacher education: Philosophical frameworks and models for teaching. Urban Review, 33, 87-105.

Justiz, M. J., \& Kameen, M. C. (1988). Increasing the representation of minorities in the teaching profession. Peabody Journal of Education, 66(1), 91-100.

Kagan, D. M. (1992). Professional growth among preservice and beginning teachers. Review of Research in Education, 62, 129-169.

Knight-Abowitz, K. (2000). A pragmatist revisioning of resistance theory. American Educational Research Journal, 37(4), 877-907. 
Ladson-Billings, G. (1990). Culturally relevant pedagogy. The College Board Review, 155, 20 25.

Ladson-Billings, G. (1995). Multicultural teacher education: Research, practice, and policy. In J. A. Banks \& C. A. McGee Banks (Eds.), Handbook of research on multicultural education (pp. 747-759). New York: MacMillan.

Lowenstein, L. K. (2009). The work of multicultural teacher education: Reconceptualizing white teacher candidates as learners. Review of Educational Research, 79(1), 163196.

McLaren, P. (1994). Critical Pedagogy, political agency, and the pragmatics of justice: the case of Lyotard. Educational Theory, 44(3), 319-40.

MacDonald, S., Colville-Hall, S., \& Smolen, L. (2003). Program ownership and the "transformative agenda" in the colleges of education: Teachers of teachers working towards a more equitable society. Multicultural Education, 10(4), 7-14.

Milner, H. R. (2005). Stability and change in U.S. prospective teachers' beliefs and decisions about diversity and learning to teach. Teaching and Teacher Education, 21, 767-786.

Montalto, V. N. (1982). A history of the intercultural education movement 1924 - 1941. New York: Garland.

Murrell, C. P. (2001). The community teacher: A new framework for effective urban teaching. New York: Teachers' College Press.

National Center for Educational Statistics. (2003). National assessment of educational progress. The nation's report card: 2003 mathematics and reading results. Retrieved from http://nces.ed.gov/nationalreportcard/reading/results2003/raceethnicity.asp

National Council for Accreditation of Teacher Education. (2008). The standards of excellence in teacher preparation. Retrieved from http://www.ncate.org

Nieto, S. (1998). From claiming hegemony to sharing space: Creating community in multicultural education courses. In R. Chavez \& J. O'Donnell (Eds.), Speaking the unpleasant: The politics of (non)engagement in multicultural education terrain (pp. 16-31). Albany: State University of New York Press.

Nieto, S. (2000). Placing equity front and center: Some thoughts on transforming teacher education for a new century. Journal of Teacher Education, 51(3), 180-187.

Payne, R. C., \& Welsh, H. B. (2000). The progressive development of multicultural education before and after the 1960s: A theoretical framework. In A. C. Grant \& K. T. Chapman (Eds.), History of multicultural education, Vol. 2 (pp. 346-360).

Pohan, C. A. (1996). Preservice teachers' beliefs about diversity: Uncovering factors leading to multicultural responsiveness. Equity and Excellence in Education, 29(3), 62-70.

Ramirez, M., \& Castaneda, A. (1974). Cultural democracy, biocognitive development and education. New York: Academic Press. 
Ramsey, J. P. (2010). Bilingual public schooling in the United States: A history of America's "polyglot boardinghouse." New York: Palgrave Macmillan.

Richardson, V. (1996). The role of attitudes and beliefs in learning to teach. In J. Sikula, J. Buttery, \& E. Guyton (Eds.), Handbook of research on teacher education, 2nd ed. (pp. 17). New York: Macmillan.

Ross, D. D., \& Smith, W. (1992). Understanding preservice teachers' perspectives on diversity. Journal of Teacher Education, 43(2), 94-103.

Rountree, C. (2004) Brown v. Board at fifty: A rhetorical perspective. Lanham, MD: Lexington Books.

Sleeter, C., \& Grant, C. (2003). Making choices for multicultural education: Five approaches to race, class, and gender. New York: Merrill.

Smith, B. O. (1969). Teachers for the real world. Washington. D. C.: American Association of Colleges for Teacher Education.

Smith, R., Moallem, M., \& Sherrill, D. (1997). How pre-service teachers think about cultural diversity: A closer look at factors which influence their beliefs towards equality. Educational Foundations, 11(2), 41-61.

Taylor, S. V., \& Sobel, D. M. (2001). Addressing the discontinuity of students' and teachers' diversity: A preliminary study of preservice teachers' beliefs and perceived skills. Teaching and Teacher Education, 17, 487-503.

Tosh, J., \& Lang, S. (2006). The pursuit of history. London: Pearson.

U.S Bureau of Census (2000). Washington DC: The U.S Bureau of Census.

Weisman, E. M., \& Garza, S. A. (2002). Preservice teachers attitudes toward diversity: Can one class make a difference? Equity and Excellence in Education, 35(1), 28-34.

Zeichner, K. M. (1996). Educating teachers for cultural diversity. In K. Zeichner, S. Melnick, \& M. L. Gomez (Eds.), Currents of reform in preservice teacher education (pp. 133175). New York: Teachers College Press.

Zeichner, K. M., \& Hoeft, K. (1996). Teacher socialization for cultural diversity. In J. Sikula, T. J. Buttery, \& E. Guyton (Eds.), Handbook of research on teacher education, 2nd ed. (p. 22). New York: Macmillan. 